\title{
Utilization of Yellowfin Tuna and Red Snapper Roe Protein Concentrate as Emulsifier in Mayonnaise
}

\author{
Safira Yessica Wiharja ${ }^{1}$, Joko Santoso ${ }^{2}$ and Lisa Amanda Yakhin ${ }^{1}$ \\ 1. Department of Food Technology, Faculty of Industrial Technology, Universitas Pelita Harapan, Lippo Karawaci, Tangerang \\ 15811, Indonesia
}

2. Department of Aquatic Products Technology, Faculty of Fisheries and Marine Sciences, Bogor Agricultural University, Campus IPB Dramaga Bogor 16680, Indonesia

Received: October 10, 2013 / Published: December 20, 2013.

\begin{abstract}
Roes of yellowfin tuna (Thunnus albacares) and red snapper (Lutjanus champecanus) are considered as abundant and underutilized by-product in Indonesia. The production of roe protein concentrate (RPC) is expected to increase the economic value and potency of their usage. Tuna and red snapper RPC was defatted using etanol $95 \%$ with one, two, three and four times of repetition. Both RPC made with four times repetition of defatting had the highest protein content (79.90\% and $80.72 \%$ ), showed high emulsion activity (97.46\% and 99.62\%) and emulsion stability (97.10\% and 99.48\%), and decreased the interfacial tension of 51\% and 55.9\%, respectively. Mayonnaise was made with 0, 25, 50, 75 and 100\% substitution level of each RPC with four times repetition of defatting. The physical, chemical and organoleptic properties of mayonnaise were studied. The best mayonnaise formulation was obtained from $50 \%$ substitution level of tuna and red snapper RPC. Mayonnaise with tuna and red snapper RPC had good viscosity $(5,920 \mathrm{cPs}$ and $5,845 \mathrm{cPs})$, high emulsion stability $(90.5 \%$ and $91.73 \%)$ and small fat globule size $( \pm 2.5 \mu \mathrm{m}$ and $\pm 2.25 \mu \mathrm{m})$, respectively. These mayonnaises also showed high score of spreadability and low intense of fishy odor. However they still had quite strong of fishy flavor based on scoring test.
\end{abstract}

Key words: Emulsifier, mayonnaise, red snapper, yellowfin tuna, RPC.

\section{Introduction}

Yellowfin tuna (Thunnus albacares) and red snapper (Lutjanus champecanus) are two fish species abundantly found in Indonesia. Fish processing industries of tuna and red snapper produce large quantities of fish roe daily. Those two kinds of fish roes are categorized as underutilized source of raw material in Indonesia due to their undesirable odour and highly perishable nature. Majority of fisheries by-products are presently used in the production of fertilizer, fish meal and pet food that have no economic value. By-product utilization will improve the economic aspects of processing industry and further their functional and nutritional beneficiation. An experiment [1] reported

Corresponding author: Safira Yessica Wiharja, B.Sc., research field: food product development. E-mail: safirayessica@yahoo.com. that protein extracted from fish roes were high quality protein and had desirable emulsifying properties. Furthermore, fish roes were also reported to be a good source of protein and amino acid [2,3].

Roes of tuna and red snapper can be converted into a higher value food ingredient by processing them into roe protein concentrate (RPC). Research on fish protein concentrate (FPC) from several types of fish meats has been widely developed, however literature on protein concentrate made from fish roes from tropical water fish is still limited. Therefore, the investigation on physico-chemical and emulsifying properties of RPC were conducted in this research. The repetition in defatting step was estimated to maximize the protein content and the emulsion properties of both RPC [4].

Mayonnaise is oil-in-water $(\mathrm{o} / \mathrm{w})$ emulsion that traditionally uses egg yolk as emulsifier. Nevertheless, 
the risk of Salmonella sp. contamination in raw egg yolk, the fluctuation of price and quality of eggs, and high cholesterol content in egg yolk have affected the growing of research about the alternative source of emulsifier in the last few years. Several types of proteins are used as emulsifiers in food since they can improve the surface properties of an emulsion by forming a protective steric barrier around the oil droplet [5]. The emulsification properties of animal proteins such as whey, lactoglobuline, casein and several vegetable protein from soy, white lupin or tomato seed have been proven successfully in stabilizing oil-in-water $(\mathrm{o} / \mathrm{w})$ emulsion $[6,7]$. It may be possible to use tuna and red snapper RPC as the alternative sources of emulsifier in $\mathrm{o} / \mathrm{w}$ emulsion system such as mayonnaise. This research was conducted to determine the best amount of defatting step repetition in producing tuna and red snapper RPC to study emulsifying and physico-chemical properties of RPC, and to determine the best RPC concentration on egg yolk substitution of mayonnaise formulation.

\section{Materials and Methods}

\subsection{Production of Tuna and Red Snapper RPC}

Yellowfin tuna (Thunnus albacares) roes and red snapper (Lutjanus champecanus) roes were collected from comercial fish processing plant in Muara Baru and Muara Angke, North Jakarta. Fish roes were immediately brought to the laboratory and stored at $4{ }^{\circ} \mathrm{C}$ for less than $2 \mathrm{~h}$ before further processing. Production of RPC referred to a new method developed with modification $[8,9]$. Fish roes were separated from blood vessels and skins, then washed with cold water $\left(5{ }^{\circ} \mathrm{C}\right) . \mathrm{NaCl}(1 \%, \mathrm{w} / \mathrm{w})$ and $\mathrm{NaHCO}_{3}(1.3 \%$, w/w) were then added on fish roes. Homogenization of fish roes made with food processor for 30 seconds at $10{ }^{\circ} \mathrm{C}$. The resulting homogenate was defatted using $95 \%$ ethanol (food grade) $\left(20 \mathrm{~min}, 5{ }^{\circ} \mathrm{C}\right)$ with the ratio of raw material $(\mathrm{g})$ :ethanol $(\mathrm{mL})=1: 3$. The mixture was continuously stirred with high-speed magnetic stirrer. The solvent was decanted and the defatting process was repeated for two, three and four times for maximum removal of lipid. The residue was dried using a cabinet dryer at a temperature of $40{ }^{\circ} \mathrm{C}$ for $8 \mathrm{~h}$. Defatted and dried roes were ground to powder using a blender and sieved using a 60 mesh Tyler sieve. Tuna and red snapper RPC with the most optimum number of repetitions in defatting step were selected based on analysis of protein content, fat content, aroma and degree of whiteness.

\subsection{Physico-Chemical Characteristics of Roes and $R P C$}

All roes and RPC samples were analyzed in duplicate for moisture, ash, total protein and crude fat content using standart methods [10]. Colors of tuna and red snapper RPC were determined using a Minolta chromameter (Model CR-400) and reported as $L^{*}, a^{*}$ and $b^{*}$ values. Degree of whiteness of RPC samples was calculated by the following equation.

$$
\begin{gathered}
\text { Degree of wihteness }(\%)= \\
100 \%-\left[(100-L)^{2}+a^{2}+b^{2}\right]^{0.5}
\end{gathered}
$$

Amino acid analyses of tuna and red snapper RPC were analyzed by reversed-phase high performance liquid chromatography (HPLC) in gradient composition system using 60\% acetonitrile-AccQ-tag effluent $\mathrm{A}$ as mobile phase and monitored using fluorescence detector at $250 \mathrm{~nm}$.

\subsection{Emulsifying Properties}

Emulsifying activity (EA) and emulsifying stability (ES) of RPC samples were measured according to the method of an Australian group study [11]. 5\% RPC suspension was made in distilled water. The $\mathrm{pH}$ of the suspension was adjusted to 3, 4.5, 6, 7.5 and 9, then the volume of the suspension was also adjusted to $75 \mathrm{~mL}$ by adding distilled water. $75 \mathrm{~mL}$ of vegetable oil were added gradually to the suspension, then homogenized using blender for $2 \mathrm{~min}$. The emulsion was later centrifuged at $4,000 \mathrm{rpm}$ for $30 \mathrm{~min}$. Sample preparation for ES determination was similar to that of EA, with an additional step of heating at $80{ }^{\circ} \mathrm{C}$ for 25 
min prior to centrifugation. EA and ES were calculated as percentage of the total volume of the emulsified suspension after centrifugation.

Interfacial tension of RPC samples were measured using du Nouy tensiometer [12]. 5\% RPC suspension was poured into a crystalline dish and the platinum ring was completely submerged. Vegetable oil was carefully poured on top of RPC suspension to form the two-layer system. Interfacial tension relates to the force (dyne/cm) required to pull a wire ring (platinum ring) off the interface of water and oil.

\subsection{Water Absorption Capacity (WAC) and Fat} Absorption Capacity (FAC)

WAC and FAC of RPC samples were measured by placing $500 \mathrm{mg}$ of RPC sample into a $15 \mathrm{~mL}$ centrifuge tube and adding $10 \mathrm{~mL}$ distilled water (WAC measurement) or $10 \mathrm{~mL}$ vegetable oil (FAC measurement). The mixture was thoroughly mixed with spatula, kept for $30 \mathrm{~min}$ at $25{ }^{\circ} \mathrm{C}$ with intermittent mixing every $10 \mathrm{~min}$, then centrifuged at 3,000 rpm for $25 \mathrm{~min}$. WAC or FAC calculated as percentage of water or oil that can be absorbed by the RPC sample [13].

\subsection{Preparation of Mayonnaise Containing Tuna and Red Snapper RPC}

Five mayonnaise formulations were prepared for each tuna and red snapper RPC. Four of the mayonnaise formulations contained RPC with various substitution levels to egg yolk $(25 \%, 50 \%, 75 \%$ and $100 \%$ ). Mayonnaise with $100 \%$ traditional egg yolk formulation was used as control. The basic formulation of mayonnaise (per $100 \mathrm{~g}$ ) included $80 \mathrm{~g}$ soybean oil, $6 \mathrm{~g}$ egg yolk, $7.5 \mathrm{~g}$ water, $1.5 \mathrm{~g}$ vinegar, $1.5 \mathrm{~g}$ lemon juice, $1.5 \mathrm{~g}$ garlic, $1 \mathrm{~g}$ salt, $1 \mathrm{~g}$ sugar and $0.5 \mathrm{~g}$ pepper. Mayonnaise was made by adding egg yolk, tuna or red snapper RPC, seasonings and $15 \mathrm{~mL}$ of soybean oil which was mixed for 30 seconds using high speed stick mixer. $35 \mathrm{~mL}$ of soybean oil was then added into mayonnaise mixture at rate of $0.5 \mathrm{~mL} /$ second while continuously stirred at high speed. The rest of vegetable oil $(30 \mathrm{~mL})$ was later mixed into mayonnaise mixture and stirred with high speed for 30 seconds. Vinegar and lemon juice were added into the mixture and stirred using baloon whisk for 15 seconds.

\subsection{Evaluation of Mayonnaise Containing Tuna and Red Snapper RPC}

Two main physical properties of resulted mayonnaise (i.e., viscosity and emulsion stability) were measured and evaluated. The emulsion viscosity was measured at room temperature using a Brookfield model DV-I + viscometer with spindle No. 6 and No. 7 at $100 \mathrm{rpm}$. Yield stress of mayonnaise emulsion was the maximum value observed [14]. The emulsion stability of mayonnaise was measured by transferring $15 \mathrm{~g}$ of each sample to centrifugation tube, then centrifugated them for $30 \mathrm{~min}$ at $5,000 \mathrm{rpm}$. The emulsion stability was calculated as percentage of the total weight of the precipitated fraction to total weight of mayonnaise before centrifugation. Fat globule size of the best substitution level of each mayonnaise samples were also evaluated using Olympus microscope connected to a digital camera at the magnification of 40 [7].

\subsection{Sensory Evaluation}

Fishy odor of tuna and red snapper RPC with all treatments of defatting repetition was assessed by five-point scale scoring test. Thirty semi-trained panelists of male and female undergraduate students of Food Technology Department at Universitas Pelita Harapan were involved in this test. Scoring test was also conducted on the mayonnaise samples after one-day storage at $7{ }^{\circ} \mathrm{C}$. Sensory characteristics tested including appearance, fishy odor, fishy taste and spreadability were evaluated by 30 semi-trained panelists on five-point scoring scale, one-the most/highest; five - the least/lowest.

\subsection{Statistical Analysis}

Mean values from the three replicate analyses were 
reported. A general linear model of one way analysis of variance (ANOVA) was used to observe significant differences $(P<0.05)$ among treatments, followed by post hoc Tukey HSD test.

\section{Results and Discussion}

\subsection{Proximate Composition of Tuna and Red Snapper} Roe

Tuna roe contained $72.94 \% \pm 0.11 \%$ moisture, $18.42 \% \pm 0.36 \%$ protein, $6.30 \% \pm 0.39 \%$ fat and $1.43 \% \pm 0.15 \%$ ash, while red snapper roe contained $70.12 \% \pm 0.78 \%$ moisture, $17.48 \% \pm 0.32 \%$ protein, $7.63 \% \pm 0.40 \%$ fat and $1.28 \% \pm 0.22 \%$ ash. These two kinds of fish roe have relatively high protein content which consists of $75 \%$ ovoglobuline, $11 \%$ albumine, $13 \%$ collagen and 2\%-3\% non-protein nitrogen compound. Protein contents of tuna and red snapper roes are relatively higher than cape hake by-products $(15.1 \%)$, but lower than catfish roe $(28.1 \%)[15,16]$. Fat content in fish roes tends to be higher than in fish meat. Fish roes contain high amount of polyunsaturated fatty acid (PUFA), especially omega-3 (EPA and DHA) [17]. An experiment [18] reported that the dominant minerals found in tuna roes are potassium and phosphorus. The proximate composition of fish roes depends on the species, the age of fish, seasons, environment, feed and type of processing $[2,19]$.

\subsection{Physico-chemical and Organoleptic} Characteristics of Tuna and Red Snapper RPC

Physico-chemical and organoleptic characteristics of tuna and red snapper RPC with various amount of defatting steps are presented in Table 1. Protein and fat content are the main quality parameters of RPC. It was observed that protein and fat content of both RPC were influenced significantly $(P<0.05)$ by the amount of defatting process. An increase in protein content and a decrease in fat content of tuna and red snapper roes were in line with the increasing amount of defatting step by $95 \%$ ethanol. The result obtained is accordance with the statement of Ref. [8] that ethanol had polar and non-polar groups which could bind water and fat. Thus, the loss of fat and water extracted will be greater as the amount of deffating step increase. The results were in agreement with the previous studies $[9,20]$ of FPC made from several types of fresh water fish which showed similar effect of defatting repetition to the protein and fat content.

The RPC obtained from tuna was light yellowish in colour, whereas the product from red snapper possessed darker colour. RPC should be brightly colored to be easily applied in various food products [21]. Table 1 shows that the degree of whiteness of tuna and red snapper RPC increased with the increasing amount of defatting repetition. Ref. [22] explained that fat contained in fish and fisheries by-products tended to be yellow, and hence the more fat is extracted, the resulting RPC colors are brighter. In addition, the fat soluble-carotenoid pigments (i.e., lutein, astaxanthin, canthaxantine, $\beta$-carotene and $\beta$-cryptoxanthine) contained in fish roes are also extracted during defatting process.

Aroma is also one of the parameters used for RPC quality determination. Good quality of FPC should have weak fishy odor [21]. Table 1 shows a significant effect $(P<0.05)$ between the amount of defatting repetition to score of fishy odor in both RPC. Tuna and red snapper RPC with the lowest intensity of fishy odor are derived from four-time repetition of defatting stage. Red snapper RPC tends to have stronger fishy odor than tuna RPC due to the higher fat content. The higher the fat content, the more unsaturated fatty acids will be oxidized to form 6-8-9 carbonyl and alcohol compounds that produce a distinctive odor and fishy odor in RPC [23].

Tuna and red snapper RPC with four-time defatting steps meet all the quality requirements of the high quality of FPC due to the highest protein content, the lowest fat content, the highest degree of whiteness and the lowest intensity of fishy odor. Protein contents of tuna and red snapper RPC with four-time defatting step were more than $67.5 \%$, which meet the requirements of 
Table 1 Physico-chemical and organoleptic characteristics of tuna and red snapper RPC with all treatments of defatting repetition.

\begin{tabular}{llllll}
\hline Sample & $\begin{array}{l}\text { Amount of defatting step } \\
\text { (time) }\end{array}$ & Protein (\%) & Fat (\%) & Degree of whiteness (\%) & Score of fishy odor \\
\hline \multirow{3}{*}{ Tuna RPC } & 1 & $74.19 \pm 1.43^{\mathrm{a}}$ & $6.07 \pm 0.18^{\mathrm{d}}$ & $62.29 \pm 0.07^{\mathrm{q}}$ & $2.90 \pm 0.88^{\mathrm{a}}$ \\
& 2 & $76.14 \pm 1.44^{\mathrm{ab}}$ & $4.89 \pm 0.18^{\mathrm{c}}$ & $62.86 \pm 0.09^{\mathrm{b}}$ & $2.97 \pm 0.96^{\mathrm{a}}$ \\
& 3 & $76.98 \pm 1.68^{\mathrm{ab}}$ & $3.67 \pm 0.26^{\mathrm{b}}$ & $63.91 \pm 0.24^{\mathrm{c}}$ & $3.13 \pm 0.86^{\mathrm{ab}}$ \\
& 4 & $79.90 \pm 1.46^{\mathrm{b}}$ & $2.83 \pm 0.06^{\mathrm{a}}$ & $64.34 \pm 0.25^{\mathrm{c}}$ & $3.33 \pm 0.81^{\mathrm{b}}$ \\
\hline \multirow{3}{*}{ Red snapper RPC } & 1 & $70.86 \pm 1.61^{\mathrm{w}}$ & $8.78 \pm 0.76^{\mathrm{z}}$ & $62.52 \pm 0.24^{\mathrm{w}}$ & $2.80 \pm 0.85^{\mathrm{wx}}$ \\
& 2 & $74.23 \pm 0.92^{\mathrm{wx}}$ & $7.38 \pm 0.48^{\mathrm{y}}$ & $63.04 \pm 0.20^{\mathrm{wx}}$ & $2.23 \pm 0.57^{\mathrm{w}}$ \\
& 4 & $75.77 \pm 0.70^{\mathrm{wx}}$ & $5.56 \pm 0.23^{\mathrm{x}}$ & $64.07 \pm 0.68^{\mathrm{xy}}$ & $3.00 \pm 1.11^{\mathrm{x}}$ \\
\hline
\end{tabular}

Values are means \pm standard deviation of triplicate determinations;

Means with the different letter in each column are significantly different $(P<0.05)$ for every parameter on each RPC.

type A FPC. However, fat content of tuna RPC is only eligible for type B (max. 3\%), while red snapper RPC only fulfill type $\mathrm{C}$ standart (max. 10\%). Based on the overall analysis results, both of these RPC with the best treatment of defatting can be classified in the type B FPC according to standard established by the FAO [21].

\subsection{Amino Acid Analysis}

Amino acid contents of tuna and red snapper RPC with the best treatment of defatting step are listed in Table 2. Components of non-essential amino acids that largely composed both types of RPC were glutamic acid, arginine and aspartic acid. Tuna and red snapper RPC was also high in essential amino acids (leucine, lysine, threonine, valine, threonine and phenylalanine). Previous studies [18] had noticed similar pattern of amino acid composition in the skipjack, tongol and bonito roe. Tuna RPC had hydrophobic (non-polar) and hydrophilic (polar) groups of amino acid for 335.19 $\mathrm{mg} / \mathrm{g}$ protein and $509.08 \mathrm{mg} / \mathrm{g}$ protein, respectively, while red snapper RPC had hydrophobic and hydrophilic group of amino acids for $341.79 \mathrm{mg} / \mathrm{g}$ protein and $504.91 \mathrm{mg} / \mathrm{g}$ protein, respectively. As pointed out by Ref. [24], the higher the hydrophobicity of a protein, the stronger protein adsorbed at interface, thus the ability to stabilize the emulsion will be better.

\subsection{Emulsifying Properties of RPC}

Emulsion activity demonstrates the ability of protein
Table 2 Amino acid composition (mg/g protein) of RPC.

\begin{tabular}{|c|c|c|c|}
\hline Amino acid & & $\begin{array}{l}\text { Tuna } \\
\text { RPC }\end{array}$ & $\begin{array}{ll}\text { Red snapper } \\
\text { RPC }\end{array}$ \\
\hline \multirow{10}{*}{ Essential amino acid } & Valine & 48.60 & 52.69 \\
\hline & Methionine & 28.02 & 24.72 \\
\hline & Lysine & 51.14 & 57.71 \\
\hline & Isoleucine & 42.17 & 44.25 \\
\hline & Leucine & 69.75 & 76.92 \\
\hline & Phenylalanine & 53.88 & 42.06 \\
\hline & Threonine & 50.73 & 46.96 \\
\hline & Cysteine & 24.66 & 21.30 \\
\hline & Tyrosine & 50.23 & 42.58 \\
\hline & Total & 418.66 & 409.18 \\
\hline \multirow{7}{*}{$\begin{array}{l}\text { Non-essential amino } \\
\text { acid }\end{array}$} & Aspartic acid & 56.60 & 62.29 \\
\hline & Serine & 41.91 & 40.34 \\
\hline & Glutamic acid & 99.46 & 112.15 \\
\hline & Glysine & 33.27 & 32.25 \\
\hline & Alanine & 43.65 & 47.30 \\
\hline & Proline & 49.62 & 53.85 \\
\hline & Total & 324.53 & 348.18 \\
\hline \multirow{3}{*}{$\begin{array}{l}\text { Semi-essential amino } \\
\text { acid }\end{array}$} & Arginie & 70.85 & 63.86 \\
\hline & Histidine & 31.23 & 25.47 \\
\hline & Total & 102.08 & 89.33 \\
\hline Total amino acid & & 845.26 & 846.69 \\
\hline
\end{tabular}

Polar amino acid: lysine, histidine, threonin, serine, systein, glysine, aspartic acid, glutamic acid, arginine and tyrosin;

Non-polar amino acid: valine, methionine, isoleucine, leucine, phenylalanine, alanine and proline.

to form and stabilize emulsion by interfacial action. Emulsion stability is the ability of emulsion droplets to remain dispersed without undergoing coalescence, flocculation and creaming by measuring its resistance to extreme temperature changes [25]. Emulsion 
activity and stability of tuna and red snapper RPC were measured at $\mathrm{pH} 3,4.5,6,7.5$ and 9 as presented in Fig. 1. Activity and stability of tuna and red snapper RPC were relatively low at $\mathrm{pH}$ 3-6 and reached a minimum point at $\mathrm{pH} 4.5$. The higher values of emulsion activity and stability of both RPC were obsereved between $\mathrm{pH}$ 7.5 and $\mathrm{pH} 9$, and reached the maximum point at $\mathrm{pH} 9$. Thus, the isoelectric points of tuna and red snapper $\mathrm{RPC}$ were estimated to be at $\mathrm{pH}$ 4.5. Higher emulsion activity and stability were observed in red snapper RPC than that of tuna RPC. The different hydrophobic groups in amino acid composition of both RPC might cause the difference in emulsification properties.

Interfacial tension indicates the effectiveness of an emulsifier in stabilizing emulsion system. Interfacial tension between oil and water surface before and after the addition of 5\% RPC was obsereved in this research. Results for interfacial tension measurement are presented in Table 2. The addition of 5\% tuna and red snapper RPC could decrease the interfacial tension of $51 \%$ and $55.91 \%$, respectively, which were comparable to egg yolk that decreased the interfacial tension of $51.72 \%$. Lower value of interfacial tension will facilitate the formation of more stable emulsion [26]. Red snapper RPC decreased the interfacial tension greater than egg yolk and tuna RPC since it had slightly more amount of hydrophobic group of amino acid.

\subsection{WAC and FAC of RPC}

WAC of tuna and red snapper RPC was found to be $538.30 \pm 11.48$ and $625.36 \pm 19.6$, respectively, and both of the RPC absorbed oil less than water (177.95 \pm 10.42 and $189.49 \pm 14.28$, respectively), which may be due to the presence of more polar groups of amino acid in the protein concentrate that bind water molecules [27]. FAC of tuna RPC was found to be lower than that of red snapper RPC as red snapper RPC has slightly higher hydrophobic group of amino acid than tuna RPC. Friberg [25] explained that the ability of both RPC to absorb more water than fat might help the dispersion of oil in water, resulting in the formation of oil-in-water (o/w) emulsion.

The emulsion viscosity of different mayoniase formulations are presented in Fig. 2a. The viscosity generally increased as the substitution level of tuna and red snapper RPC to egg yolk increased. A significantly higher viscosity of mayonnaise was obtained from $75 \%$ and $100 \%$ substitution level of both RPC to egg yolk. The highest viscosity was obtained from mayonnaise formulated with $100 \%$ tuna and red snapper RPC. These results were an agreement with Ref. [28] that an increase of emulsion viscosity is proportional to an increase of protein concentration. Proteins can form a thin layer (film) that surrounds fat globule. Higher protein concentration is expected to form thicker layer of absorbed protein at interface, and hence the immobilization of fat globules and water molecules will be higher which causes an increase in viscosity.

\subsection{Physical Properties of Mayonnaise Containing Tuna and Red Snapper RPC}

The emulsion stability of mayonnaise samples was determined by centrifugation to accelerate the possibility of emulsion destabilization. It was found that mayonnaise with various substitution levels of tuna and red snapper RPC to egg yolk were generally fairly high in emulsion stability, even though a significantly decrease $(P<0.05)$ of the emulsion stability was observed as the substitution levels of both RPC increase (Fig. 2b). This could be due to the partial dissolution of RPC in oil and water which cause some amount of RPC precipitate after centrifugation.

\subsection{Sensory Evaluation of Mayonnaise Containing Tuna and Red Snapper RPC}

Organoleptic properties are also important in mayonnaise product as they affect the acceptance of the product. Five-scale of scoring test was conducted in mayonnaise product and the results are presented in Table 3. The increase of fishy odor and fishy flavor score in mayonnaise samples containing tuna and red 


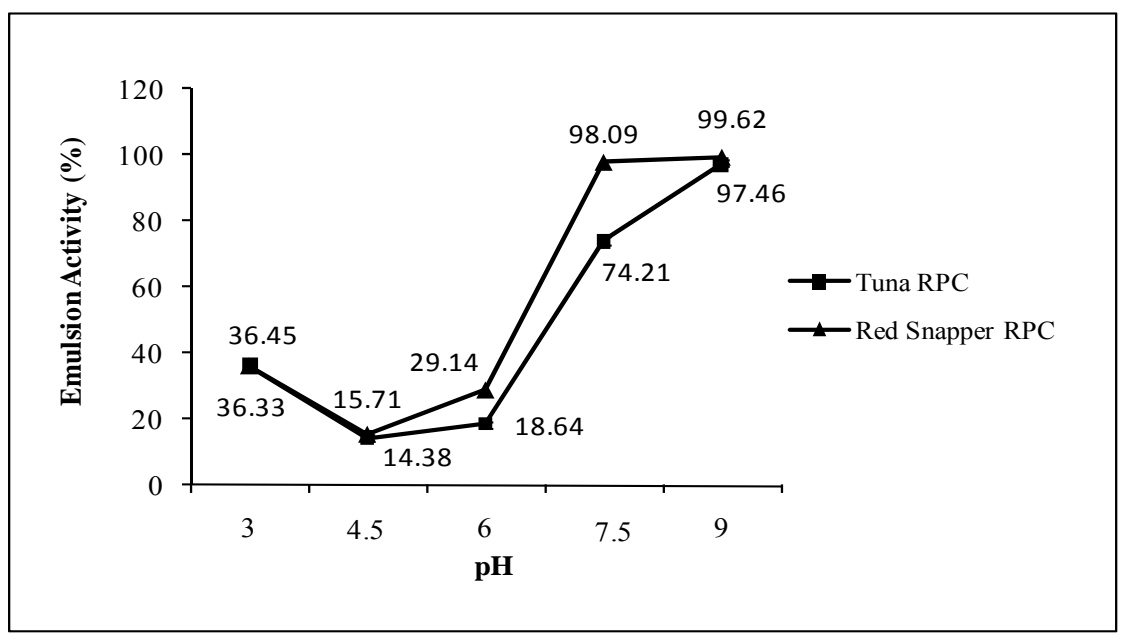

Fig. 1 Emulsion activity and emulsion stability of tuna and red snapper RPC at various pH.

Table 2 Interfacial tension of RPC and egg yolk.

\begin{tabular}{lc}
\hline Sample & Interfacial tension $($ Dyne $/ \mathrm{cm})$ \\
\hline Control (oil-water) & $218.20 \pm 4.48$ \\
Tuna RPC & $106.92 \pm 3.24$ \\
Red snapper RPC & $96.20 \pm 1.88$ \\
Egg yolk & $105.35 \pm 3.91$ \\
\hline
\end{tabular}

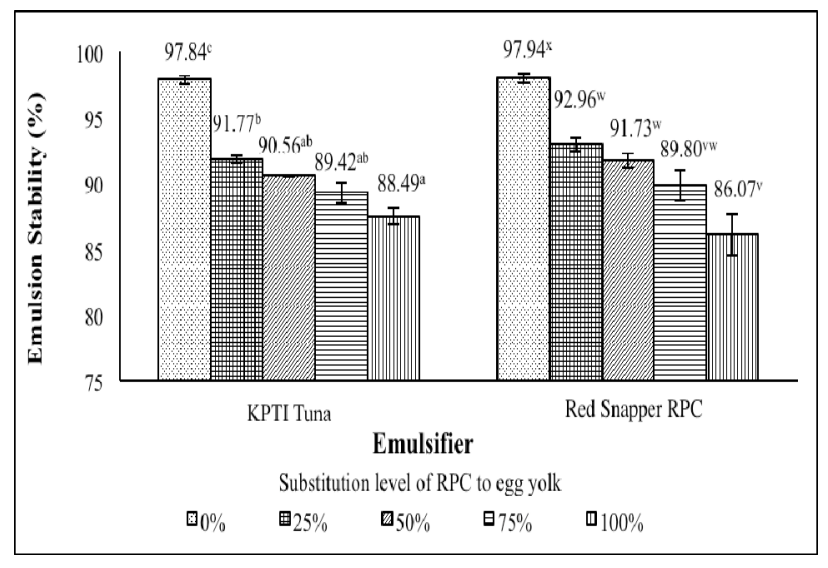

(a)

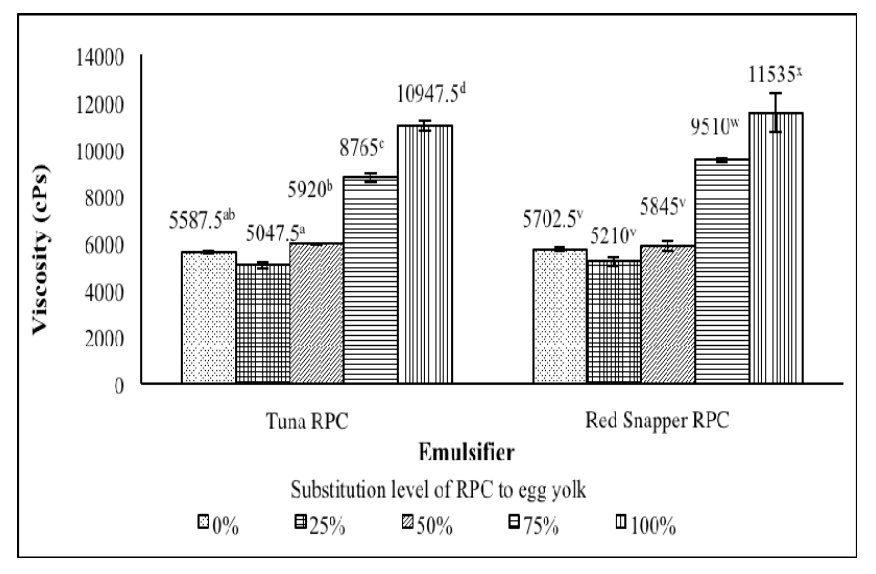

(b)

Fig. 2 The effects of substitutution level of tuna and red snapper RPC to (a) emulsion stability and (b) viscosity on mayonnaise formulation; means with the different letters in each column are significantly different $(P<0.05)$.

snapper RPC were in line with the increase of substititution levels of both RPC. A sinificantly $(P<$ $0.05)$ stronger fishy odor of mayonnaise was found at $75 \%$ and $100 \%$ level of substitution. Mayonnaise samples containing tuna and red snapper RPC were still considered to have strong fishy flavour at most levels of substitution. Generally, mayonnanaise containing tuna RPC tends to have stronger fishy odor and fishy flavor than mayonnaise with red snapper
RPC. This could be due to the higher levels of fat oxidation in red snapper RPC which contributes stronger specific fishy flavor. Mayonnaise was also found to have high score of spreadability in most levels of substitution. Mayonnaise with the highest score of spreadibility was obtained from $0 \%$ and $25 \%$ substitution levels, while mayonnaise samples with $100 \%$ substitution level were observed to have the lowest score of spreadibiliy. A study [16] reported that 
Table 3 Organoleptic properties of mayonnaise containing tuna and red snapper RPC.

\begin{tabular}{|c|c|c|c|c|c|}
\hline Sample & Substitution level of RPC to egg yolk & $(\%)$ & Score of fishy flavour & Score of fishy odor & Score of spreadability \\
\hline \multirow{5}{*}{$\begin{array}{l}\text { Mayonnaise } \\
\text { containing tuna } \\
\text { RPC }\end{array}$} & 0 & & $3.93 \pm 0.87^{\mathrm{b}}$ & $3.93 \pm 0.74^{\mathrm{b}}$ & $4.40 \pm 0.56^{\mathrm{b}}$ \\
\hline & 25 & & $3.37 \pm 1.10^{\mathrm{ab}}$ & $2.53 \pm 1.07^{\mathrm{a}}$ & $4.37 \pm 0.56^{\mathrm{b}}$ \\
\hline & 50 & & $3.27 \pm 1.11^{\mathrm{ab}}$ & $2.60 \pm 1.22^{\mathrm{a}}$ & $4.27 \pm 0.52^{\mathrm{ab}}$ \\
\hline & 75 & & $2.90 \pm 0.99^{\mathrm{a}}$ & $2.30 \pm 1.15^{\mathrm{a}}$ & $4.17 \pm 0.70^{\mathrm{ab}}$ \\
\hline & 100 & & $2.83 \pm 1.18^{\mathrm{a}}$ & $2.33 \pm 0.96^{\mathrm{a}}$ & $3.90 \pm 0.66^{\mathrm{a}}$ \\
\hline \multirow{5}{*}{$\begin{array}{l}\text { Mayonnaise } \\
\text { containing red } \\
\text { snapper RPC }\end{array}$} & 0 & & $3.23 \pm 1.17^{\mathrm{W}}$ & $3.07 \pm 1.14^{\mathrm{x}}$ & $4.10 \pm 0.76^{\mathrm{VW}}$ \\
\hline & 25 & & $2.80 \pm 0.92^{\mathrm{vw}}$ & $2.43 \pm 0.73^{\mathrm{w}}$ & $4.43 \pm 0.50^{\mathrm{w}}$ \\
\hline & 50 & & $2.73 \pm 0.94^{\mathrm{vw}}$ & $2.33 \pm 0.80^{\mathrm{vw}}$ & $4.20 \pm 0.66^{\mathrm{vw}}$ \\
\hline & 75 & & $2.50 \pm 1.11^{\mathrm{v}}$ & $2.03 \pm 0.96^{\mathrm{vw}}$ & $4.00 \pm 0.69^{\mathrm{vw}}$ \\
\hline & 100 & & $2.43 \pm 0.86^{\mathrm{V}}$ & $1.73 \pm 0.69^{\mathrm{v}}$ & $3.77 \pm 0.63^{v}$ \\
\hline
\end{tabular}

Values are means \pm standard deviation of triplicate determinations;

Means with the different letters in each column are significantly different $(P<0.05)$ for each type of mayonnaise.

Table 4 Characteristics of the best mayonnaise formulation and commercial mayonnaise.

\begin{tabular}{llll}
\hline Parameter & Mayonnaise containing tuna RPC & Mayonnaise containing red snapper RPC & Commercial mayonnaise \\
\hline Viscosity (cPs) & $5920 \pm 20^{\mathrm{a}}$ & $5845 \pm 212.13^{\mathrm{a}}$ & $7220 \pm 169.71^{\mathrm{b}}$ \\
Emulsion stability $(\%)$ & $90.56 \pm 0.06^{\mathrm{a}}$ & $91.73 \pm 0.56^{\mathrm{a}}$ & $100 \pm 0.00^{\mathrm{b}}$ \\
Fat globule size $(\mu \mathrm{m})$ & \pm 2.5 & \pm 2.25 & \pm 1.75 \\
Protein content $(\%)$ & $3.45 \pm 0.14^{\mathrm{b}}$ & $3.65 \pm 0.03^{\mathrm{b}}$ & $0.88 \pm 0.03^{\mathrm{a}}$ \\
\hline
\end{tabular}

Values are means \pm standard deviation of triplicate determinations;

Means with the different letters in each column are significantly different $(P<0.05)$.

the addition of protein may result firmer emulsion due to stronger interaction between fat globule. The addition of too large amount of RPC may result a very firm texture of mayonnaise which makes it difficult to spread.

\subsection{Characteristics of the Best Mayonnaise Formulation}

Mayonnaise samples with $50 \%$ substitution level of tuna and red snapper RPC were considered as the best formulation due to their good physical and organoleptic properties. In addition, results of ANOVA showed that those mayonnaise samples have the most similar characteristics with the control mayonnaise. Furthermore, those mayonnaise samples were compared to the commercial mayonnaise (Table 4). Viscosity and emulsion stability of commercial mayonnaise are significantly higher $(P<0.05)$ than RPC substituted mayonnaise. The increase in viscosity is generally followed by an increase in emulsion stability and firmness [26]. Commercial mayonnaises mostly use thickening agents (i.e., starch and add a stabilizer), resulting in firmer texture and higher viscosity. Commercial mayonnaise has the smallest fat globule size $( \pm 1.75 \mu \mathrm{m})$, followed by mayonnaise with red snapper RPC $( \pm 2.25 \mu \mathrm{m})$ and mayonnaise with tuna RPC $( \pm 2.5 \mu \mathrm{m})$. Dickinson and Stainsby [5] explained that the viscosity and emulsion stability of an emulsion would increase as the fat globule size decreased. The partial substitution of tuna and red snapper RPC to egg yolk in mayonnaise formulation could significantly increase $(P<0.05)$ the protein content of both mayonnaise formulations.

\section{Conclusions and Suggestions}

Tuna and red snapper RPC with four repetitions in defatting process were classified as type B of FPC based on FAO standard. Emulsion stability and emulsion activity of those two types of RPC reached its maximum point at $\mathrm{pH} 9$ and its minimum point at $\mathrm{pH}$ 4.5. Tuna and red snapper RPC were able to decrease the interfacial tension for $51 \%$ and $55.91 \%$, respectively. Both types of RPC tend to absorb more 
water than fat due to their hydrophobicity. It was also reported that red snapper RPC has slightly more hydrophobic groups of amino acid than tuna RPC (i.e., $341.79 \mathrm{mg} / \mathrm{g}$ protein and $335.19 \mathrm{mg} / \mathrm{g}$, respectively). Tuna and red snapper RPC could partially substitute the use of egg yolks as emulsifier in mayonnaise formulation up to $50 \%$ and gave fairly high viscosity, high emulsion stability and small size of fat globule. The best mayonnaise formulation was considered to have low intense of fishy odor, high score of spreadability, however it still had strong intense of fishy flavor based on scoring test. This research demonstrated that tuna and red snapper RPC can be utilized as safe and sustainable emulsifier in producing oil in water emulsion based product such as mayonnaise.

Further research regarding the most optimum type of solvent to extract fat in fish roes needs to be done. The ratio of oil and water that were added in mayonnaise formulation also need to be studied further to produce better characteristics of mayonnaise. Mayonnaise with tuna and red snapper RPC are also more appropriately applied in fisheries-related products and other savory food products.

\section{References}

[1] S. Sathivel, H. Yin, P.J. Bechtel, M.K. Joan, Physical and nutritional properties of catfish roe spray dried protein powder and its application in an emulsion system, Journal of Food Engineering 95 (2009) 76-81.

[2] K.A. Mahmoud, M. Linder, J. Fanni, M. Parmentier, Characterisation of the lipid fractions obtained by proteolytic and chemical extractions from rainbow trout (Oncorhynchus mykiss) roe, Process Biochemistry 43 (2008) 376-383.

[3] S. Mol, S. Turan, Comparison of proximate, fatty acid and amino acid compositions of various types of fish roes, International Journal of Food Properties 11 (2008) 669-677.

[4] M.K. Chalamaiah, G. Balaswamy, R. Narsing, P.G. Prabhakara, T. Jyothirmayi, Chemical composition and functional properties of mrigal (Cirrhinus mrigala) egg protein concentrates and their application in pasta, Journal of Food Science and Technology, 2011. DOI: 10.1007/s13197-011-0357-5.
[5] E. Dickinson, G. Stainsby, Coloid in Foods, Applied Science, New York, 1982.

[6] A. Raymundo, J.M. Francob, J. Empisc, I. Sousad, Optimization of the composition of cow-fat oil in-water emulsions stabilized by white lupin protein, Journal of the American Oil Chemists' Society 79 (2002) 783-790.

[7] V. Nikzade. M.M. Tehrani, M. Saadatmand-Tarzjan, Optimization of low cholesterole-low fat mayonnaise formulation: Effect of using soy milk and some stabilizer by a mixture design approach, Journal of Food Hydrocolloids 28 (2012) 344-452.

[8] T. Suzuki, Fish and Krill Protein, Applied Science Publishing Ltd., London, 1981.

[9] G.S. Hartono, Utilization of fish protein concentrate of tilapia fish (Oreochromis mossambicus) on baby biscuit, Thesis, Faculty of Industrial Technology, Pelita Harapan University, Tangerang, 2011. (in Indonesia)

[10] AOAC, Official Methods of Analysis of the Association of Official Analytical Chemists, AOAC Inc., USA, 2005.

[11] V. Jayasena, H.J. Chih, S.M. Nasar-Abbas, Functional properties of sweet lupin protein isolated tested at various $\mathrm{pH}$ levels, Journal of Agriculture and Biological Sciences 6 (2) (2010) 130-137.

[12] ASTM D_1331, Standard Test Methods Surface and Interfacial Tension of Surface Active Agents and Emulsions, Annual Book of ASTM Standards, Vol. 15, Easton MD, Philadelphia, 2000.

[13] F. Shahidi, J.R. Botta, Seafoods: Chemistry, Processing Technology and Quality, Chapman and Hall, Great Britain, 1994.

[14] G. Gaonkar, K. Rathna, C. Ken, C. Bruce, Emulsifying functionality of enzyme-modified milk protein in $\mathrm{o} / \mathrm{w}$ and mayonnasie-like emulsion, Journal of Food Engineering 84 (2008) 348-357.

[15] C. Pires, S. Costa, A.P. Batista, M.C. Nunes, A. Raymundo, I. Batista, Properties of protein powder prepared from Cape hake by-products, Journal of Food Engineering 108 (2012) 268-275.

[16] S. Sathivel, H. Yin, P.J. Bechtel, M.K. Joan, Physical and nutritional properties of catfish roe spray dried protein powder and its application in an emulsion system, Journal of Food Engineering 95 (2009) 76-81.

[17] M.D. Huynh, D.D. Kitts, C. Hu, A.W. Trites, Comparison of fatty acid profiles of spawning and non-spawning Pacific herring, Clupea harengus pallasi, Comparative Biochemistry and Physiology Part B, Biochemistry and Molecular Biology 146 (4) (2007) 504-511.

[18] R. Intarasirisawat, B. Soottawat, V. Wonnop, Chemical composition of the roes from skipjack, tongol and bonito, Journal of Food Chemistry 124 (2011) 1328-1334.

[19] S. Brooks, R.T. Charles, P.S. John, Egg quality in fish: What makes a good egg? Reviews in Fish Biology and 
Fisheries 7 (2007) 387-416.

[20] E.H. Putra, Utilization of fish protein concentrate of catfish (Clarias graphienus) in infant formula, Thesis, Faculty of Industrial Technology, Pelita Harapan University, Tangerang, 2011. (in Indonesia)

[21] L.M.L. Nollet, T. Boylston, F. Chen, P.C. Coggins, M.B. Gloria, Handbook of Meat, Poultry and Seafood Quality, Blackwell Publishing, USA, 2007.

[22] M.L. Windsor, Fish Protein Concentrate, Torry Research Station, USA, 2001.

[23] F. Rieuwpassa, Fish protein concentrate base biscuit enriched with probiotic as functional foods to enhance the immunity and nutritional status of underfive children, Dissertation, Postgraduate Programme of Food
Technology, Bogor Agricultural Institute, Bogor, 2005. (in Indonesia)

[24] M. Wirahadikusumah, Biochemistry: Protein, Enzym and Nucleic Acid, ITB Publishing, Bandung, 2008.

[25] S.E. Friberg, Food Emulsion, 4th ed., Marcel dekker Inc., New York, 2004.

[26] G.L. Hasensuettl, R.W. Hartel, Food Emulsifiers and Their Applications, 2nd ed., Chapman and Hall, New York, 2008.

[27] D. Nelson, M.C. Michael, Lehninger Principles of Biochemistry, 5th ed., Worth Publisher Inc., New York, 2009.

[28] Y. Pomeranz, Functional Properties of Food Components, Academic Press, San Diego, 1991. 